\title{
GIRK Channels Mediate the Nonphotic Effects of Exogenous Melatonin
}

\author{
Lauren M. Hablitz, ${ }^{1}$ Hylton E. Molzof, ${ }^{1}$ Kathryn E. Abrahamsson, ${ }^{2}$ Joanna M. Cooper, ${ }^{2}$ Rebecca A. Prosser, ${ }^{2}$ \\ and ${ }^{-K a r e n ~ L . ~ G a m b l e ~}{ }^{1}$ \\ ${ }^{1}$ Department of Psychiatry and Behavioral Neurobiology, University of Alabama at Birmingham, Birmingham, Alabama 35294, and ${ }^{2}$ Department of \\ Biochemistry and Cellular and Molecular Biology, University of Tennessee Knoxville, Knoxville, Tennessee 37996
}

Melatonin supplementation has been used as a therapeutic agent for several diseases, yet little is known about the underlying mechanisms by which melatonin synchronizes circadian rhythms. G-protein signaling plays a large role in melatonin-induced phase shifts of locomotor behavior and melatonin receptors activate G-protein-coupled inwardly rectifying potassium (GIRK) channels in Xenopus oocytes. The present study tested the hypothesis that melatonin influences circadian phase and electrical activity within the central clock in the suprachiasmatic nucleus (SCN) through GIRK channel activation. Unlike wild-type littermates, GIRK2 knock-out (KO) mice failed to phase advance wheel-running behavior in response to $3 \mathrm{~d}$ subcutaneous injections of melatonin in the late day. Moreover, in vitro phase resetting of the SCN circadian clock by melatonin was blocked by coadministration of a GIRK channel antagonist tertiapin-q (TPQ). Loose-patch electrophysiological recordings of SCN neurons revealed a significant reduction in the average action potential rate in response to melatonin. This effect was lost in SCN slices treated with TPQ and SCN slices from GIRK2 KO mice. The melatonin-induced suppression of firing rate corresponded with an increased inward current that was blocked by TPQ. Finally, application of ramelteon, a potent melatonin receptor agonist, significantly decreased firing rate and increased inward current within SCN neurons in a GIRKdependent manner. These results are the first to show that GIRK channels are necessary for the effects of melatonin and ramelteon within the SCN. This study suggests that GIRK channels may be an alternative therapeutic target for diseases with evidence of circadian disruption, including aberrant melatonin signaling.

Key words: circadian; entrainment; GIRK; melatonin; nonphotic; suprachiasmatic nucleus

\section{Significance Statement}

Despite the widespread use of melatonin supplementation for the treatment of sleep disruption and other neurological diseases such as epilepsy and depression, no studies have elucidated the molecular mechanisms linking melatonin-induced changes in neuronal activity to its therapeutic effects. Here, we used behavioral and electrophysiological techniques to address this scientific gap. Our results show that melatonin and ramelteon, a potent and clinically relevant melatonin receptor agonist, significantly affect the neurophysiological function of suprachiasmatic nucleus neurons through activation of G-protein-coupled inwardly rectifying potassium (GIRK) channels. Given the importance of GIRK channels for neuronal excitability (with $>600$ publications on these channels to date), our study should generate broad interest from neuroscientists in fields such as epilepsy, addiction, and cognition.

\section{Introduction}

The hormone melatonin, produced by the pineal gland, is a potent regulator of circadian rhythms or $24 \mathrm{~h}$ cycles in behavior and

\footnotetext{
Received April 24, 2015; revised Sept. 24, 2015; accepted 0ct. 1, 2015

Author contributions: L.M.H., R.A.P., and K.L.G. designed research; L.M.H., H.E.M., K.E.A., J.M.C., and R.A.P. performed research; L.M.H., H.E.M., K.E.A., J.M.C., R.A.P., and K.L.G. analyzed data; L.M.H. and K.L.G. wrote the paper.

This work was supported by National Institutes of Health (Grant R01NS082413 to K.L.G. and Grant F31NS084683 to L.M.H.), and the University of Tennessee (R.A.P.). We thank Russell Johnson Jr for help with animal maintenance and Rita Cowell, Catherine Fuller, Martin Young, and Linda Overstreet-Wadiche for discussing organization of the paper.
}

biological processes (Dubocovich, 2007). Exogenous melatonin has been used to treat a variety of diseases that exhibit circadian rhythm comorbidities, such as epilepsy (Banach et al., 2011; Jain and Besag, 2013), delayed sleep phase syndrome (Mundey et al., 2005), cardiometabolic diseases (Paulis et al., 2012), and mood

The authors declare no competing financial interests.

Correspondence should be addressed to Karen L. Gamble, Department of Psychiatry and Behavioral Neurobiology, University of Alabama at Birmingham, SC 721, 1720 7th Avenue South, Birmingham, AL 35294-0017. E-mail: klgamble@uab.edu.

DOI:10.1523/JNEUROSCI.1597-15.2015

Copyright $\odot 2015$ the authors $\quad 0270-6474 / 15 / 3514957-09 \$ 15.00 / 0$ 
disorders such as depression (Racagni et al., 2007; Campos Costa et al., 2013; Comai and Gobbi, 2014; Laudon and FrydmanMarom, 2014). However, the molecular mechanisms linking melatonin-induced changes in neuronal activity to regulating the timing of circadian rhythms are poorly understood.

In both humans and rodents, exogenous melatonin administered during the late day advances the phase of circadian cycle, shifting activity onset to an earlier time (McArthur et al., 1991; Benloucif and Dubocovich, 1996; Prosser, 1999; Hunt et al., 2001; Dubocovich et al., 2005; Mundey et al., 2005). Within the primary clock center of the brain, the suprachiasmatic nucleus (SCN) of the hypothalamus, melatonin application hyperpolarizes the resting membrane potential and suppresses spontaneous action potential rate in neurons within acute SCN slices from mice and rats (Jiang et al., 1995; van den Top et al., 2001; Scott et al., 2010). These effects on the circadian system are thought to be mediated through G-protein-coupled signaling. G-proteincoupled melatonin receptors mediate melatonin-induced phase shifts in behavior and changes in SCN firing rate (Hunt et al., 2001; Dubocovich and Markowska, 2005). In addition, melatonin-induced hyperpolarization of SCN neurons has been shown to be pertussis toxin sensitive (van den Top et al., 2001), indicating that $G_{\mathrm{i} / \mathrm{o}}$ heterotrimeric G-protein signaling is critical for the acute electrophysiological effects of melatonin. G-protein-coupled inwardly rectifying potassium (GIRK) channels are potential candidate mediators of this inhibitory effect of melatonin given that GIRK currents are increased by melatonin receptor activation in a Xenopus oocyte expression system (Nelson et al., 1996). Recently, we have shown that GIRK channel activation varies over the day/night cycle and that daytime activation is sufficient to induce phase advances of the molecular clock within the SCN (Hablitz et al., 2014). We hypothesize that GIRK channels mediate the phase-advancing effects of exogenous melatonin. Here, we used behavioral and electrophysiological techniques to ascertain whether GIRK channels are necessary for the inhibitory and phase-synchronizing effects of melatonin on SCN neurons and wheel-running behavior and if ramelteon, a potent clinically relevant melatonin receptor agonist (Kato et al., 2005), requires GIRK channels to alter SCN electrophysiology.

\section{Materials and Methods}

Ethical approval. All animal care, handling, and housing were in compliance with the University of Alabama at Birmingham's Institutional Animal Care and Use Committee guidelines and the University of Tennessee at Knoxville Institutional Animal Care and Use Committee.

Animals and housing. All mice in these experiments were 2-4 months of age to reduce developmental or aging phenotypes (Turek et al., 1995; Biello, 2009). Only male mice were used for behavioral experiments (Ruiz de Elvira et al., 1992; Vyazovskiy et al., 2006). GIRK2 knock-out (KO) animals on a C57BL/6 background (Signorini et al., 1997) and wild-type (WT) littermate controls were used for electrophysiology and circadian behavioral analysis. Although $\mathrm{C} 57 \mathrm{BL} / 6$ mice are melatonin deficient, studies have confirmed that melatonin binding and phaseshifting effects of melatonin are still intact and comparable to other mouse strains (Siuciak et al., 1990; Liu et al., 1997). Separate cohorts of mice were used for each different experiment. Unless otherwise stated, mice were group housed on a 12:12 light/dark (LD) cycle with food and water ad libitum.

Behavioral analysis. All mice were housed in individual wheel cages. Wheel-running activity was recorded and analyzed using Clocklab software (Actimetrics). After entrainment to a 12:12 LD cycle, mice were released into constant darkness for at least $10 \mathrm{~d}$ before treatment. Mice were then treated at $\sim \mathrm{CT} 10$ (circadian time 10 ; CT12 is defined as activity onset) with either subcutaneous injections of vehicle (100 $\mu \mathrm{l}$ of $3 \%$ ethanol/saline) or melatonin ( $100 \mu \mathrm{l}$ of $0.39 \mu \mathrm{M})$ for 3 consecutive days, as described previously (Dubocovich et al., 2005). Phase shifts were measured as the difference between two predictions for the time of activity onset the day after treatment (using linear regression for each time period pretreatment and posttreatment for each animal). The first prediction was based on the 7 onsets before the first injection and the second prediction was based on the 7 onsets after 3 stabilization days after injections. Mice that were injected before CT9.5 were excluded from analysis. When possible, mice were treated with vehicle and melatonin using a crossover design. During the experiment, 9 of $13 \mathrm{WT}$ and 6 of $7 \mathrm{KO}$ mice received both treatments with at least 2 weeks between trials.

Whole-cell and loose-patch electrophysiology. Mice were killed at ZT8.5 (Zeitgeber time 8.5; ZT12 defined as lights off) by cervical dislocation. All recordings were made between projected ZT10 and ZT12. Brains were harvested, sectioned at $200 \mu \mathrm{m}$ on a vibroslicer (7000 smz; Campden Instruments), and transferred to an open recording chamber (Warner Instruments) that was continuously perfused at a rate of $2.0 \mathrm{ml} / \mathrm{min}$ with extracellular solution consisting of the following (in $\mathrm{mM}$ ), $\mathrm{NaCl} \mathrm{124}$, $\mathrm{NaHCO}_{3} 20, \mathrm{Na}_{2} \mathrm{HPO}_{4} 1, \mathrm{MgSO}_{4} 1.3$, glucose 10, $\mathrm{KCl} 3.5$, and $\mathrm{CaCl}_{2} 2.5$ (added the day of experiment). Osmolality was adjusted to 300-305 mOsm and the solution was bubbled with $5 \% \mathrm{CO}_{2} / 95 \% \mathrm{O}_{2}$ and heated to $34 \pm 0.5^{\circ} \mathrm{C}$. Neurons were visualized with an Olympus BX51WI using infrared-differential interference contrast optics. For both whole-cell and loose-patch electrophysiology, electrodes with a pipette resistance of $\sim 4-6 \mathrm{M} \Omega$ were filled with filtered, potassium gluconate solution consisting of the following (in mM): K-gluconate 135, KCl 10, HEPES 10, and EGTA 0.5 and then adjusted to $\mathrm{pH} 7.4$ with $\mathrm{KOH}$ (Kuhlman and McMahon, 2004). Electrophysiological signals were processed and controlled by a Multiclamp 700B amplifier, and pClamp 10.02 software (Molecular Devices). Recordings were sampled at $20 \mathrm{kHz}$ and filtered at $10 \mathrm{kHz}$. The GIRK channel antagonist tertiapin-Q (TPQ; $0.2 \mu \mathrm{M}$; Alamone Laboratories) was used for the experiments in Figures 3, 4, 5, and 6. For the experiments shown in Figures 4 and 5, cells were treated with either vehicle (water) or melatonin ( $1 \mu \mathrm{M}$; Sigma-Aldrich) as described previously (Jiang et al., 1995). For the experiments shown in Figure 6, cells were treated with either vehicle (20 nM ethanol) or ramelteon (10 pm; Biotang). For the experiments in Figures 4, 5, and 6, melatonin, ramelteon, or vehicle treatments were bath applied between ZT10 and ZT12 during the entire recording period.

For whole-cell experiments, all data were collected within 6 min of membrane rupture to minimize any potential washout effects from the whole-cell recording (Schaap et al., 1999). To block synaptic transmission (as in Figs. 5, 6), bicuculline $(30 \mu \mathrm{M})$ and $\mathrm{CdCl}_{2}(200 \mu \mathrm{M})$ (SigmaAldrich), D-AP5 (50 $\mu \mathrm{M})$ and CNQX (10 $\mu \mathrm{M})$ (Abcam), and TTX $(1 \mu \mathrm{M})$ (Tocris Biosciences) were added to the bath solution. To isolate GIRK currents (Figs. 5, 6), the concentration of extracellular $\mathrm{KCl}$ was increased from 3.5 to $30 \mathrm{~mm}$ as described previously (Fu et al., 2004) and the peak inward current in response to a slow ramp $(2.5 \mathrm{~s})$ from $-140 \mathrm{mV}$ to -20 $\mathrm{mV}$ was recorded. Cells with $>100 \mathrm{pA}$ leak at a holding potential of -65 $\mathrm{mV}$ were excluded from analysis.

For loose-patch experiments, the average spike rate was calculated from at least $1 \mathrm{~min}$ of the $2 \mathrm{~min}$ trace. Loose-patch recordings were done in voltage-clamp mode without a command hold potential. For all electrophysiological experiments, at least three biological replicates with at least four cells per animal were used. There was no specific regional bias when recording within the SCN.

Single-unit extracellular electrophysiology. Coronal brain slices (500 $\mu \mathrm{m})$ containing the SCN prepared from male WT C57BL/6 mice were maintained in a Hatton-style brain slice dish perfused constantly with oxygenated $\left(95 \% \mathrm{O}_{2} / 5 \% \mathrm{CO}_{2}\right)$ Earle's balanced salt solution (EBSS) supplemented with glucose, bicarbonate, and gentamicin, $\mathrm{pH} 7.4$, at $37^{\circ} \mathrm{C}$. One mouse was used for each experiment and replicate experiments were performed on different mice. Drug treatments were bath applied on the first day in vitro at ZT10 by stopping perfusion and replacing the medium in the slice chamber with EBSS medium supplemented with $1 \mu \mathrm{M}$ melatonin $\pm 0.2 \mu \mathrm{M}$ TPQ for $10 \mathrm{~min}$. After treatment, the medium was replaced with drug-free medium and perfusion was reinstated. Extracellular, single-cell recordings of neuronal activity were taken on day 2 in vitro, using methods described previously (McArthur et al., 1991; Prosser, 1998, 2003). A glass micropipette containing $3 \mathrm{M} \mathrm{NaCl}$ was low- 


\section{WT}

A
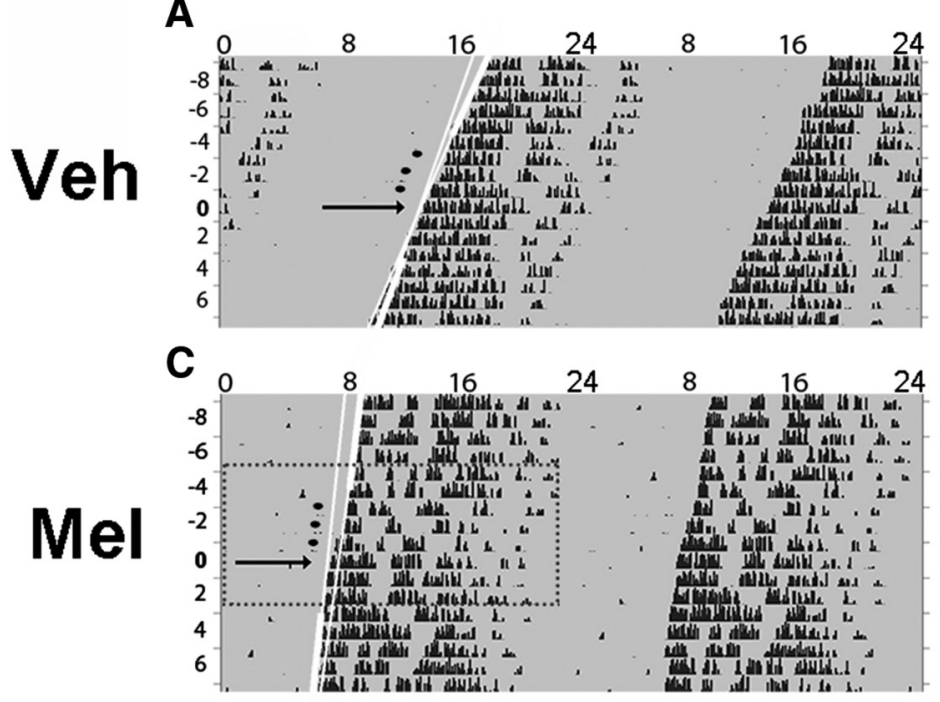

E

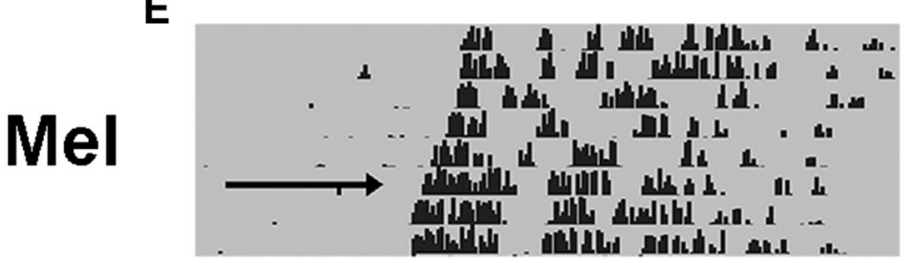

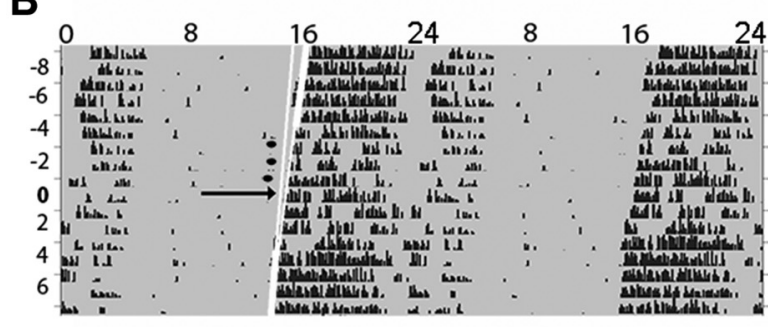

D

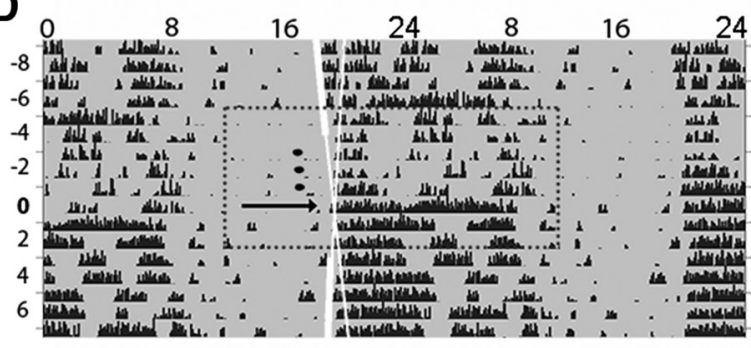

$\mathbf{F}$

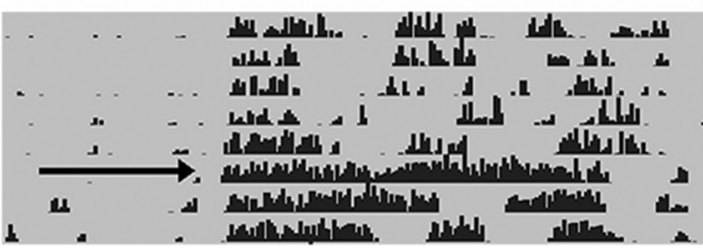

Figure 1. Melatonin-induced phase shifts in circadian activity of WT and GIRK2 KO mice. Representative, double-plotted actograms of individual WT $(\boldsymbol{A}, \boldsymbol{C}, \boldsymbol{E})$ or KO $(\boldsymbol{B}, \boldsymbol{D}, \boldsymbol{F})$ mice treated with vehicle $(\boldsymbol{A}, \boldsymbol{B})$ or melatonin $(\boldsymbol{C}-\boldsymbol{F})$ with hours indicated across the top and days on the left. WT and $K 0$ mice were housed in constant darkness (indicated by gray shading) and treated for 3 consecutive days at CT10 with either injections of $100 \mu$ l of vehicle ( $3 \%$ ethanol/saline) or melatonin $(0.39 \mu \mathrm{M})$. Treatment is indicated by black circles; best-fit lines to activity onsets are shown in white with the extended fit lines in thin white. Black arrows indicate the day after injections (used in the phase-shift predictions; see Materials and Methods). Black tick marks indicate activity counts. The areas highlighted by dotted rectangles are enlarged in $\boldsymbol{E}$ and $\boldsymbol{F}$ to compare phase shifts before and after melatonin treatment in WT and K0 animals.

ered into the SCN until the signal from an individual neuron was isolated. The cell's activity was recorded for $5 \mathrm{~min}$, after which the electrode was moved to find a new cell. Neuronal activity was sampled in this way for $10 \mathrm{~h}$. Data acquisition and analysis were done using computer software from DataWave Technologies. The firing rates of individual cells were then grouped into $2 \mathrm{~h}$ running means. Time of peak activity was determined as the time of symmetrically highest activity. The difference in time-of-peak of untreated slices versus drug-treated slices was calculated to determine phase shifts.

Statistical analysis. All statistical analysis was performed with SPSS version 22. For comparisons of means in samples with normal distributions and homogeneous variances (as indicated by a Levene's test), an independent-samples $t$ test or ANOVA was used for comparisons between two means or two or more means, respectively, followed by Fisher's LSD post hoc test when necessary. Two-factor designs were analyzed with a two-way ANOVA (using a linear mixed model with the generalized estimating equations procedure in SPSS, when appropriate). In cases of a non-normal distribution (as indicated by a Shapiro-Wilk test) or unequal variances (Levene's test), a nonparametric Kruskal-Wallis test was used, followed by median test for post hoc analyses. For categorical data, a G likelihood ratio test was used, followed by Fisher's exact test for post hoc analysis. Significance was considered to be $p<0.05$.

\section{Results}

GIRK2 is necessary for melatonin-induced phase advances of behavioral rhythms

It has been shown previously that $3 \mathrm{~d}$ subcutaneous administration of melatonin in the late-day (CT10) phase advances wheelrunning behavioral rhythms of mice (Dubocovich et al., 2005). To test the hypothesis that these phase advances are mediated by
GIRK channels, we performed a similar experiment using GIRK2 $\mathrm{KO}$ animals as a model of disrupted GIRK channel signaling compared with WT littermate controls. Administration of melatonin induced significantly larger phase advances in wheelrunning behavior compared with vehicle (linear mixed-model ANOVA, main effect of treatment, $\chi^{2}(1)=6.98, p=0.008$ ) and phase shifts in $\mathrm{KO}$ animals were overall reduced compared with WT animals (main effect of genotype, $\chi^{2}(1)=14.42, p=$ 0.00015 ; WT, $n=12-14$ per group; $\mathrm{KO}, n=7-8$ per group). This genotype effect was primarily driven by a significant interaction of genotype and treatment $\left(\chi^{2}(1)=4.22, p=0.04\right)$ such that $\mathrm{KO}$ mice had significantly smaller phase shifts in response to melatonin treatment compared with WT mice (LSD post hoc test, WTmelatonin was significantly different from: WT-vehicle, $p=$ 0.002; KO-melatonin, $p=0.006$; KO-vehicle, $p=0.002)$. These results indicate that GIRK2 is necessary for the phase-advancing effects of melatonin on behavior (Figs. 1, 2). Similar to our previous findings (Hablitz et al., 2014), GIRK2 KO animals exhibited a longer free-running period compared with WT controls (WT: $23.74 \pm 0.04 \mathrm{~h}, \mathrm{KO}: 23.87 \pm 0.04 \mathrm{~h}$; independent-samples $t$ test, $\left.t_{(37)}=2.094, p=0.043\right)$. GIRK2 $\mathrm{KO}$ animals have been shown to be hyperactive during the active phase and re-entrain more rapidly to a $6 \mathrm{~h}$ advance of a 12:12 LD cycle, but they overall have normal wheel-running activity and circadian behavior (Hablitz et al., 2014). Finally, melatonin increased free-running period equally in both WT and KO animals (post-vehicle mean: $23.77 \pm$ $0.04 \mathrm{~h}$, post-melatonin mean: $23.85 \pm 0.05 \mathrm{~h}$; repeated-measures 
ANOVA, main effect of treatment, $\left.F_{(1,34)}=4.324, p=0.045\right)$, indicating that GIRK2 is not necessary for melatonininduced effects on period length.

GIRK2 is necessary for melatonininduced phase advances of neuronal activity rhythms

In addition to phase advancing wheelrunning behavior in mice, melatonin applied in the late day (ZT10) induces phase advances in the neuronal activity rhythms of the SCN recorded in vitro (McArthur et al., 1991; Prosser, 1999). Because GIRK channels are necessary for the phaseadvancing effects of melatonin on wheel-running behavior, we tested the hypothesis that GIRK channels are necessary for melatonininduced phase advances of circadian neuronal activity rhythms in the SCN. To do this, we treated SCN brain slices from WT mice with vehicle or melatonin with or without TPQ, a GIRK channel antagonist, for $10 \mathrm{~min}$ at ZT10. The following day, we used extracellular recordings to assess phase shifts in the circadian pattern of neuronal activity. Consistent with previous reports (McArthur et al., 1991; Prosser, 1999), melatonin (1 $\mu \mathrm{M})$ application at ZT10 shifted the time of peak neuronal activity earlier on the following day (mean \pm SEM, control: ZT5.8 \pm 0.2 , melatonin: ZT3.0 \pm 0.6 ), inducing a significant phase advance compared with control recordings (one-way ANOVA, $F_{(3,8)}=5.27$, $p=0.027$; LSD post hoc test: control vs melatonin: $p=0.018$; Fig. 3), which is consistent with previous reports (McArthur et al., 1991; Prosser, 1999). TPQ alone $(0.2 \mu \mathrm{M})$ had no phase shifting effect on the SCN neuronal activity rhythm (LSD post hoc test, control vs TPQ: $p=0.613$; Fig. 3 ), with very similar peak times as control (mean \pm SEM, TPQ: ZT6.3 \pm 0.7$)$. Concurrent application of TPQ $(0.2 \mu \mathrm{M})$ and melatonin $(1 \mu \mathrm{M})$ at ZT10 prevented the melatonin-induced phase advance (LSD post hoc test, melatonin vs TPQ + melatonin: $p=0.013$; Fig. 3), resulting in similar peak times as control (mean \pm SEM, TPQ + melatonin: ZT6.0 \pm 1.0), indicating that GIRK2 is necessary for melatonin-induced phase advances of both wheel-running behavior and SCN neuronal activity rhythms.

\section{Melatonin-induced suppression of SCN neuronal activity is mediated by GIRK currents}

Previous studies have shown that melatonin suppresses action potential rates of SCN neurons both in rat (Jiang et al., 1995; Zhou et al., 2000; van den Top et al., 2001) and mouse (Scott et al., 2010). Given that GIRK channels are necessary for the phaseadvancing effects of late-day melatonin on wheel-running behavior, we tested the hypothesis that GIRK channels are necessary for the inhibitory effects of melatonin in the SCN. First, we performed loose-patch electrophysiology within the SCN. Melatonin application ( $1 \mu \mathrm{M}$, as in Jiang et al., 1995) in the late day (ZT10-ZT12) significantly decreased the spontaneous action potential frequencies of SCN neurons (mean \pm SEM, vehicle: $4.5 \pm$ $0.5 \mathrm{~Hz}$, melatonin: $3.1 \pm 0.4 \mathrm{~Hz}$; Kruskal-Wallis test, $\mathrm{H}(3)=$ 8.035, $p=0.045$; median post hoc test, $p=0.048$ for WT slices, vehicle vs melatonin). This effect was lost in the presence of TPQ (TPQ + melatonin: $5.0 \pm 0.5 \mathrm{~Hz}$, median post hoc test, $p=0.009$ for TPQ + melatonin vs melatonin). TPQ alone had no influence on spike rate of SCN neurons (TPQ: $4.8 \pm 0.5 \mathrm{~Hz}$; median post hoc test, $p=0.755$, vehicle vs TPQ; $n=>28$ cells/group). Con-
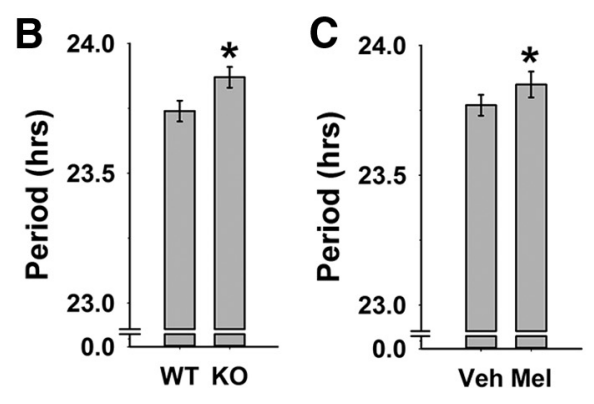

Veh

Mel

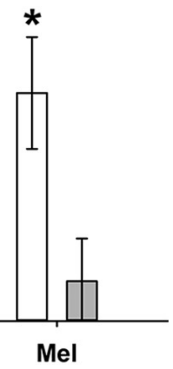

Figure 2. GIRK2 is necessary for the phase-advancing effects of melatonin on wheel-running activity. $\boldsymbol{A}$, Average phase shifts + SEM) of wheel-running activity rhythms in response to $3 \mathrm{~d}$ of subcutaneous injections at (T10 with either $100 \mu$ l of \%anol/saline) or melatonin (0.39 $\mu \mathrm{m})$ in WT and KO mice. *Significantly different from all other groups, $p<0.05 . B_{i}$ Free-running period (mean \pm SEM) for KO and WT mice before treatments. C, Cumulative free-running period (mean \pm SEM) after treatment with either vehicle or melatonin. ${ }^{*} p<0.05$.

tingency analysis revealed that the percentage of cells that had a firing rate of $<1 \mathrm{~Hz}$ varied depending on treatment group (vehicle: $11.8 \%$, melatonin: $37.0 \%$, TPQ: $6.3 \%$, melatonin + TPQ: $12.9 \%$; G likelihood ratio test, $\left.\chi^{2}(3)=15.1, p=0.002\right)$. Without $\mathrm{TPQ}$, melatonin significantly increased the percentage of lowspiking cells (Fisher's exact test, $p=0.004$ ) and this effect was lost in the presence of TPQ (Fisher's exact test, $p=0.321$ ). Similar to TPQ, melatonin application to SCN slices from GIRK2 KO mice did not suppress firing rate when applied during the late day $(\mathrm{KO}$ vehicle: $4.6 \pm 0.5 \mathrm{~Hz}, \mathrm{KO}$ melatonin: $5.1 \pm 0.5 \mathrm{~Hz}$; independent samples $t$ test, $t_{(88)}=-0.692, p=0.49, n=>44$ cells per group), indicating that GIRK channels are necessary for the decreased firing rate in response to melatonin (Fig. 4).

Melatonin receptor activation has been shown to activate GIRK channels in a Xenopus oocyte expression system (Nelson et al., 1996), yet it remains unknown whether melatonin activates GIRK channels directly within SCN neurons. To measure a melatonin-sensitive GIRK current in SCN neurons, we used whole-cell, voltage-clamp electrophysiology and pharmacological inhibition of synaptic transmission ( $1 \mu \mathrm{M}$ TTX, $30 \mu \mathrm{M}$ bicuculline, $50 \mu \mathrm{M} \mathrm{D}-\mathrm{AP} 5,10 \mu \mathrm{M}$ CNQX, and $200 \mu \mathrm{M} \mathrm{CdCl}_{2}$ ), along with increased $\mathrm{KCl}(30 \mathrm{~mm}$; to increase potassium conductance as in Hablitz et al., 2014), in response to a slow ramp (2.5 s) from $-140 \mathrm{mV}$ to $-20 \mathrm{mV}$. We found that melatonin increased peak inward current during this protocol (mean \pm SEM, vehicle: $-56.6 \pm 5.8$ pA, melatonin: $-113.6 \pm 10.2$ pA; Kruskal-Wallis test, $\mathrm{H}(3)=20.98, p=0.0001$; median post hoc test, $p=0.001$ for vehicle vs melatonin) and this effect was lost in the presence of TPQ (TPQ + melatonin: $-61.4 \pm 8.6 \mathrm{pA}$, median post hoc test, $p=0.001$ for TPQ + melatonin vs melatonin; $n=>17$ cells per group; Fig. 5). In addition, melatonin failed to increase inward current in GIRK2 KO neurons (KO vehicle: $-69.8 \pm 6.5 \mathrm{pA}, \mathrm{KO}$ melatonin: $-55.0 \pm 6.3 \mathrm{pA}$, independent samples $t$ test, $t_{(28)}=-1.603, p=0.12 ; n=13-17$ cells per group), demonstrating that melatonin is capable of activating GIRK channels in SCN neurons.

\section{GIRK channels mediate the effects of the melatonin agonist ramelteon within the SCN}

Ramelteon is a MT1/2 receptor agonist used in treating sleep disorders, depression, and delirium (Borja and Daniel, 2006; Hatta et al., 2014). This therapeutic agent can cause similar phase shifts to the circadian cycle (Rawashdeh et al., 2011) and has a higher affinity for melatonin receptors than melatonin (Kato et al., 2005; Miyamoto, 2009). Here, we tested whether ramelteon acts upon similar mechanisms as melatonin within the SCN, 
A
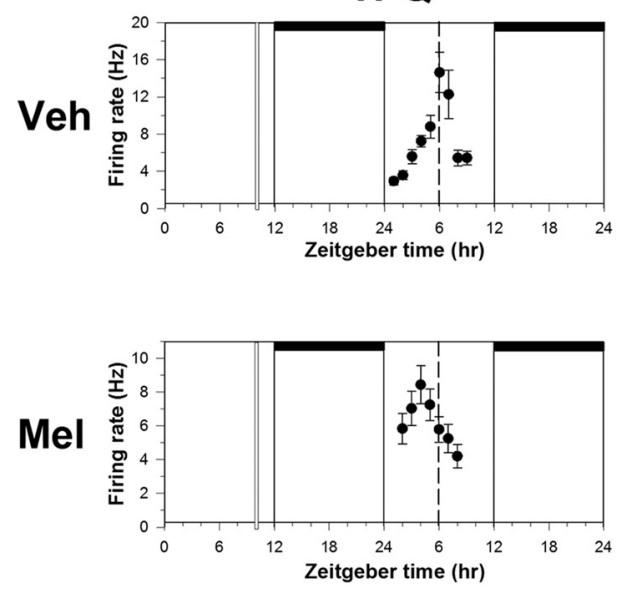
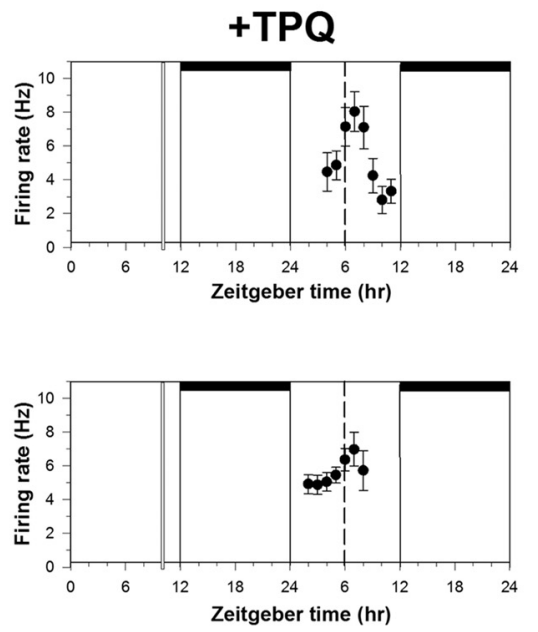

B

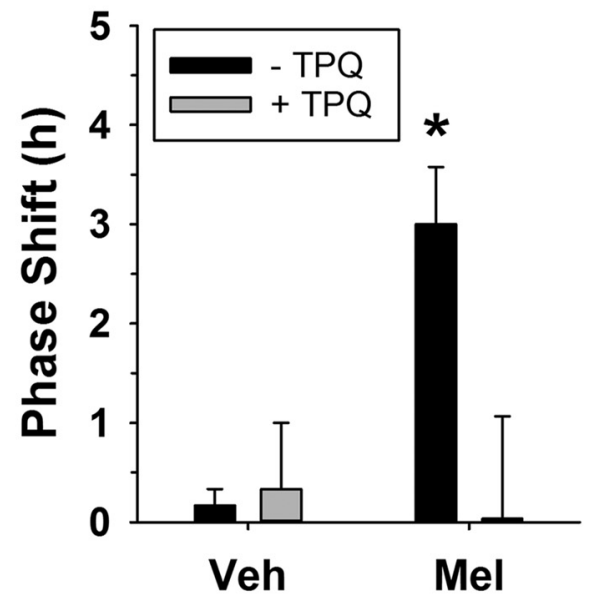

Figure 3. In vitro melatonin phase resetting requires GIRK channel activation. $\boldsymbol{A}$, Representative neuronal activity recordings from four individual experiments. Shown are the $2 \mathrm{~h}$ means \pm SEM of SCN neuronal activity obtained in a control experiment (top left) and in experiments in which slices were treated at ZT10 on the first day in vitro with the compounds indicated. Horizontal bars indicate time of lights off in the animal colony; vertical bars, time of drug treatment; dashed line, mean time-of-peak in control experiments. $\boldsymbol{B}$, Mean + SEM phase shifts induced by treatments applied for 10 min at ZT10 to SCN brain slices. ${ }^{*} p<0.05$.
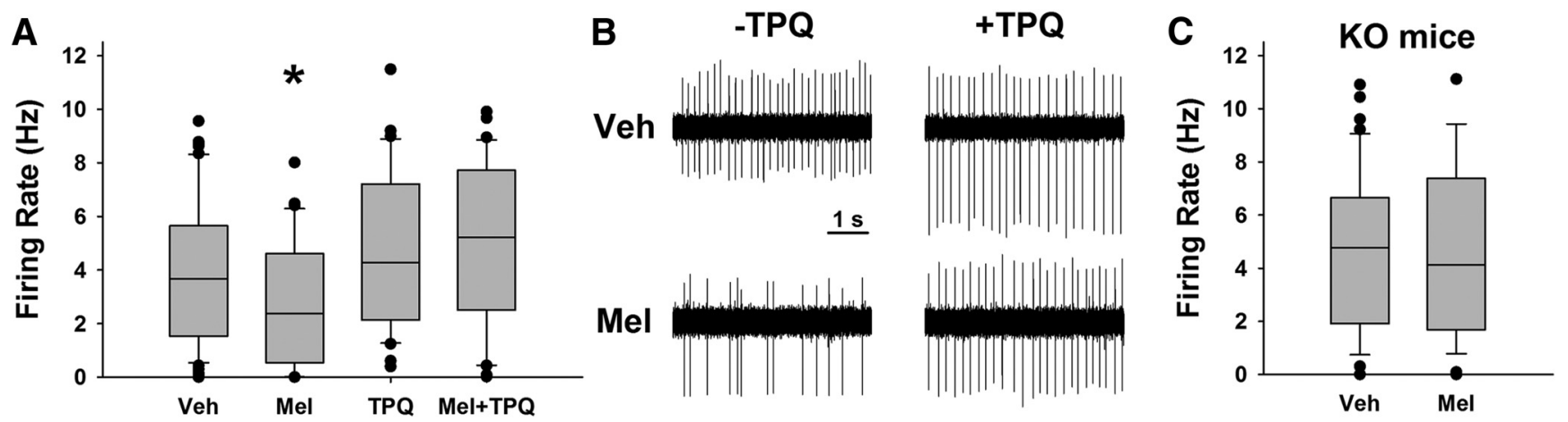

Figure 4. GIRK channels are necessary for melatonin-induced suppression of SCN action potential firing. $A$, Box plots of action potential rates for vehicle- and melatonin (1 $\mu \mathrm{m}$ )-treated cells during ZT10 -ZT12 in the presence and absence of TPQ $(0.2 \mu \mathrm{M}) .{ }^{*} p<0.05$. B, Representative loose-patch traces $(5 \mathrm{~s})$ from different individual neurons within each group in $\boldsymbol{A}$. $\boldsymbol{C}$, Box plots of action potential rates for vehicle- and melatonin (1 $\mu \mathrm{m})$-treated cells during ZT10 -ZT12 in GIRK2 K0 SCN slices.

thereby inducing GIRK currents and suppressing action potential rates. The results indicated that ramelteon application $(10 \mathrm{pM}$, from ZT10-ZT12) significantly decreased the spike rates of SCN neurons (mean \pm SEM, vehicle: $3.5 \pm 0.4 \mathrm{~Hz}$, ramelteon: $2.0 \pm$ $0.3 \mathrm{~Hz}$ ) and this effect was gone in the presence of TPQ (TPQ: $3.5 \pm 0.5 \mathrm{~Hz}$, TPQ + ramelteon: $3.3 \pm 0.5 \mathrm{~Hz}$; Kruskal-Wallis test, $\mathrm{H}(3)=14.89, p=0.002$; Fig. 6). Moreover, this inhibition corresponded to an increased inward current that was sensitive to TPQ (two-way ANOVA, ramelteon by TPQ interaction: $F_{(1,119)}=8.122, p=0.005$; simple-effects analysis: ramelteon vs vehicle: $p=0.0001$, ramelteon vs TPQ: $p=0.842$; Fig. $6 ; n=>23$ cells per group), similar to melatonin treatment (Fig. 6). Altogether, these results indicate that GIRK channels are a downstream target of melatonin receptor activation by ramelteon.

\section{Discussion}

The molecular mechanisms underlying decreased neuronal firing and phase shifts induced by late-day melatonin within the SCN are largely unknown. Here, we propose that GIRK channels mediate this suppression of firing rate and are necessary for melatonin-induced phase shifts. Indeed, we show that melatonin fails to phase advance circadian activity rhythms of mice in the absence of GIRK2 channels. Moreover, in vitro phase advances induced by melatonin are inhibited by coadministration of the GIRK inhibitor TPQ. Furthermore, melatonin did not suppress spontaneous action potential rates of SCN neurons when GIRK channels were blocked or genetically ablated. This melatonininduced decrease in spike rate corresponded to activation of a TPQ-sensitive GIRK current. These results support the hypothesis that GIRK channel activation is necessary within the SCN to convey the phase-shifting properties of melatonin on the circadian clock. Because melatonin is a key molecule to treat sleep disorders, depression, and several other diseases, we examined the effects of ramelteon, a clinical sleep aid and potent MT1/2 receptor agonist, on SCN neurophysiological response. We found that ramelteon required GIRK channel activation to suppress SCN firing rate. To our knowledge, our study is the first to investigate this acute inhibitory effect of ramelteon on neuronal excitability. Altogether, these results indicate that GIRK channels are a potential therapeutic target in diseases in which melatonin signaling has been disrupted.

Prior work has investigated the role of potassium channels in mediating the effects of melatonin. Indeed, in rats (Jiang et al., 1995; van den Top et al., 2001) and mice (Scott et al., 2010), melatonin hyperpolarizes the membrane and decreases SCN 

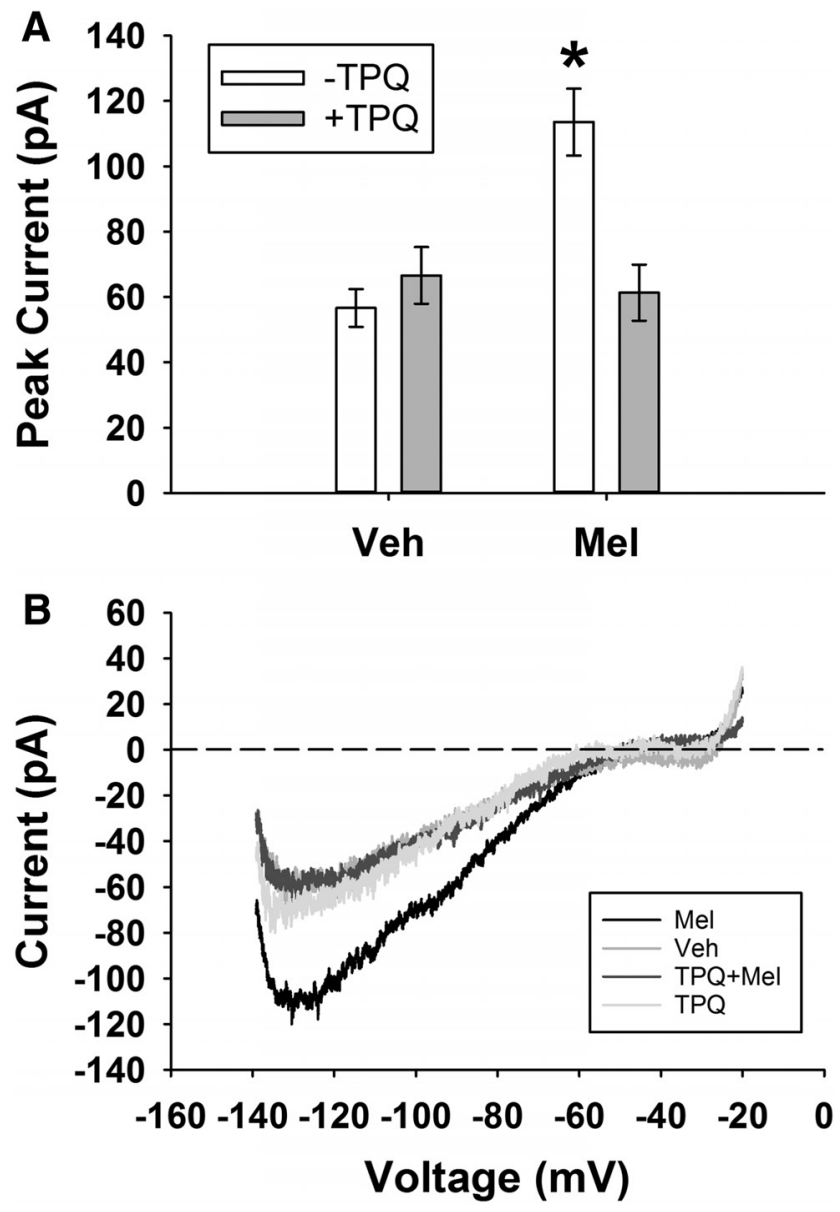

Figure 5. Melatonin induced an inward GIRK current in SCN neurons. $A$, Peak inward current (mean \pm SEM) for vehicle- and melatonin $(1 \mu \mathrm{M})$-treated cells during ZT10 -ZT12 in the presence and absence of TPQ $(0.2 \mu \mathrm{m}) .{ }^{*} p<0.05$. $\boldsymbol{B}$, Representative voltage-clamp ramp traces from different individual neurons within each group. Recordings were done in the presence of TTX (1 $\mu \mathrm{m})$, bicuculline $(30 \mu \mathrm{m}), \mathrm{D}-\mathrm{AP5}(50 \mu \mathrm{m}), \mathrm{CNQX}(10 \mu \mathrm{m})$, and $\mathrm{CdCl}_{2}(200 \mu \mathrm{m})$ to block synaptic transmission and $30 \mathrm{~mm} \mathrm{KCl}$ to increase potassium conductance.

firing. In rat SCN, melatonin-induced suppression occurs through two different mechanisms. First, melatonin reduces a hyperpolarization-activated cation current $\left(I_{\mathrm{h}}\right)$ in $\sim 40 \%$ of SCN cells by $\sim 8-13 \%$ (Jiang et al., 1995). A second mechanism of melatonin-induced suppression is via activation of a potassiumdependent outward current (when neurons are held at -40 and $-60 \mathrm{mV}$ ) that reverses between -87.1 and $-98 \mathrm{mV}$ (Jiang et al., 1995; van den Top et al., 2001). In addition, dose-response curves (Jiang et al., 1995) and pertussis toxin (a $G_{\mathrm{i} / \mathrm{o}}$ antagonist) application in the presence of melatonin (van den Top et al., 2001) supports the hypothesis that the effects of melatonin on SCN electrical activity is dependent upon G-protein-coupled MT1/2 receptors. At physiological potentials, excitability is reduced by activation of GIRK channels that conduct a small outward potassium current (Lüscher and Slesinger, 2010), similar to the melatonin-induced current in previous studies (Jiang et al., 1995; van den Top et al., 2001). Melatonin also alters GABAergic transmission within the SCN (Scott et al., 2010). Future studies should investigate the role of GIRK channels in modulating GABAergic transmission in response to nonphotic signals, which our study does not address due to the presence of GABA receptor antagonists during isolation of GIRK currents. Finally, it is important to note that melatonin may alter SCN excitability through additional mechanisms, including other ion channels.
Similar to melatonin, our previous work shows that neuropeptide Y (NPY) signaling within the SCN is also mediated through GIRK channels (Hablitz et al., 2014). Importantly, activation of GIRK channels during the day is sufficient to phase advance organotypic SCN cultures (as reported by PER2::luciferase) similar to in vivo phase response curves for both NPY (Huhman and Albers, 1994; Besing et al., 2012) and melatonin (McArthur et al., 1991; Hastings et al., 1992; Benloucif and Dubocovich, 1996; Hunt et al., 2001; Dubocovich, 2007). This type of phase-response curve with maximal phase advances during the day is characteristic of several neurotransmitters that signal for the presence of "nonphotic" stimuli (i.e., not driven by light-induced activation of the retinohypothalamic tract) such as arousal and exercise (Challet, 2007). Interestingly, these neurotransmitters (melatonin, NPY, serotonin, and GABA) are mediated through $G_{\mathrm{i} / \mathrm{o}}$ heterotrimeric G-protein signaling (Muraki et al., 2004; Dubocovich, 2007; Fowler et al., 2007; van den Pol, 2012), indicating that there may be shared common mechanisms for resetting circadian clock phase. Here, we show that GIRK channels are necessary for both melatonin-induced SCN neuronal response and in vivo and in vitro phase advances. Together with our prior study, we propose that GIRK channel activation is a putative conserved mechanism for nonphotic signals to influence the circadian clock.

Although the present study found that melatonin-induced changes in SCN neurophysiology were mediated through GIRK channels, little is known about how exogenous melatonin may regulate the molecular clock, a transcription-translation feedback loop (Roenneberg and Merrow, 2005; Partch et al., 2014) that drives circadian rhythms on a molecular level throughout different tissue types. A single injection of melatonin in the late day does not influence molecular clock levels on the first day, but does significantly change expression of Per1, Per3, Bmal1, and AVP on the second day (Poirel et al.,

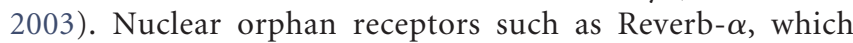
have been implicated in melatonin signaling (Agez et al., 2007), may mediate this effect. In addition, mice with a CLOCK mutation show normalization of period length in the presence of melatonin or ramelteon (Shimomura et al., 2010). Future studies should investigate whether GIRK channel activation ultimately influences components of the molecular clock such as regulation of Reverb- $\alpha$ (Agez et al., 2007; Agez et al., 2009), influencing the redox state of the cell (BonnefontRousselot and Collin, 2010; Luchetti et al., 2010; García et al., 2014), or second messenger pathways such as PKC activation (Luchetti et al., 2010), all of which have been implicated in melatonin signaling. It is important to emphasize that, although GIRK channels are necessary for melatonin-induced phase advances, this does not preclude the involvement of coactivation of $\mathrm{PKC}$ in response to melatonin. Indeed, studies measuring SCN ensemble firing in rats and rhythmic PKC expression in cell culture have demonstrated that PKC activation via MT1/2 receptors plays a key role in the phase-shifting effects of melatonin (McArthur et al., 1997; Rivera-Bermudez et al., 2003; Rivera-Bermudez et al., 2004). Activation of alternative signaling cascades could explain previous work suggesting that the inhibitory and phase-shifting effects of melatonin are through separate pathways (Liu et al., 1997; Dubocovich and Markowska, 2005). Several of these pathways, such as PKC activation, antagonize GIRK channel function (Lüscher and Slesinger, 2010), which could lead to the previously reported inhibition of serotonin-induced phase shifts of SCN electrical 
A

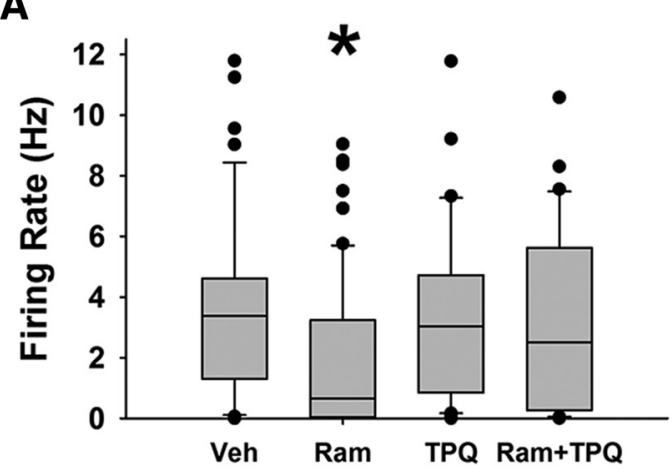

C

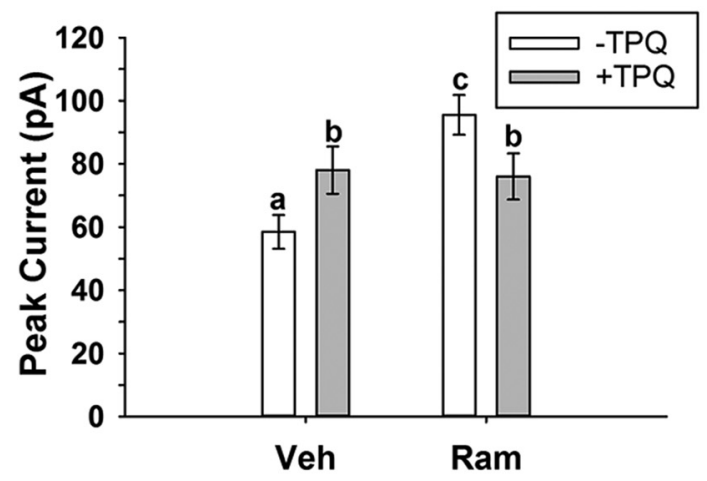

B

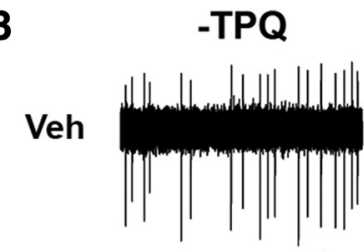

$1 \mathrm{~s}$
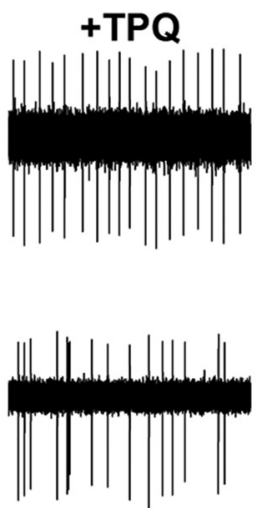

Ram

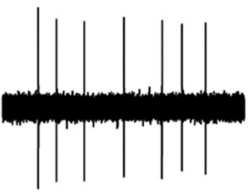

D

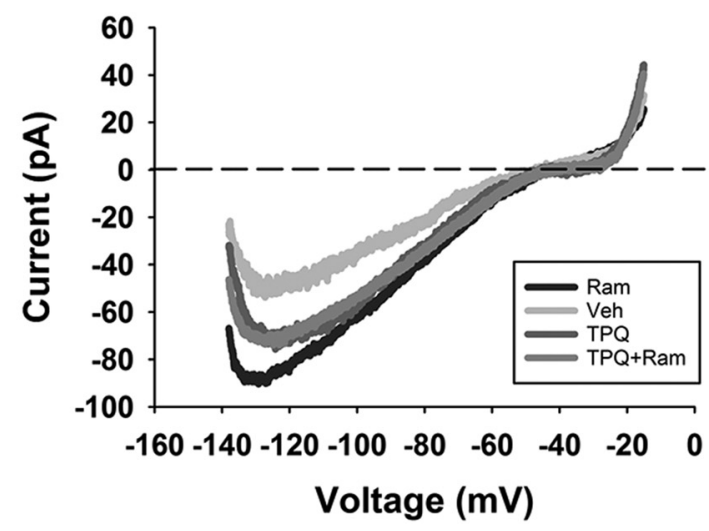

Figure 6. GIRK channels mediated the inhibitory effects of ramelteon within the SCN. A, Action potential rates (mean \pm SEM) for vehicle- and ramelteon (10 pM)-treated cells during ZT10 -ZT12 in the presence and absence of TPQ $(0.2 \mu \mathrm{M}){ }^{*} p<0.05$. $\boldsymbol{B}$, Representative loose-patch traces $(5 \mathrm{~s})$ from different individual neurons within each group in $\boldsymbol{A}$. $\boldsymbol{C}$, Peak inward current (mean \pm SEM) for vehicle- and ramelteon (10 pm)-treated cells during ZT10 -ZT12 in the presence and absence of TPQ $(0.2 \mu \mathrm{M})$. $^{*} p<0.05$. D, Representative voltage-clamp ramp traces from different individual neurons within each group. Recordings for $C$ and $\boldsymbol{D}$ were done in the presence of TTX (1 $\mu \mathrm{m})$, bicuculline (30 $\mu \mathrm{m}), \mathrm{D}-\mathrm{AP5}(50 \mu \mathrm{M}), \mathrm{CNQX}(10 \mu \mathrm{M})$, and CdCl 2 (200 $\mu \mathrm{m})$ to block synaptic transmission. Recordings in $\boldsymbol{C}$ and $\boldsymbol{D}$ were done in $30 \mathrm{~mm}$ extracellular $\mathrm{KCl}$.

activity upon coapplication of melatonin (Prosser, 1999) or NPY (Prosser, 1998).

In addition to resetting circadian phase, endogenous melatonin also provides a seasonal cue, signaling photoperiodic day length via changes in hormonal circulation patterns released from the pineal gland (Coomans et al., 2014). Classic studies have shown that changes in the length of the photoperiod cause longlasting effects on period length, such that longer or shorter photoperiods lengthen or shorten period, respectively (Pittendrigh and Daan, 1976). In the present study, we found that administration of melatonin for 3 consecutive days at CT10 was sufficient to significantly increase period length by $\sim 5 \mathrm{~min}$, indicating that acute pulses of melatonin may provide day-length information. Although this result may seem biologically insignificant, it may provide insight into circadian timing disruption in people diagnosed with mood disorders, especially considering altered melatonin receptor distribution in postmortem SCN samples from these patients (Wu et al., 2013) and successful treatment of major depressive disorder, bipolar depressive disorder, and seasonal affective disorder with melatonin receptor agonists (Srinivasan et al., 2012).

In conclusion, melatonin signaling has been shown to influence neuronal excitability, metabolic state, time-of-day, inflammation, and much more (Dubocovich et al., 2003; Dubocovich, 2007; Uberos et al., 2010; Paulis et al., 2012; Srinivasan et al., 2012). Ramelteon is clinically available and has been used to treat depression, insomnia, delirium, and Alzheimer's disease symp- toms (Borja and Daniel, 2006; Furuya et al., 2012; Hatta et al., 2014). Here, we show that the effects of both melatonin and ramelteon on the neurophysiological function of SCN neurons are mediated by GIRK channels. Diseases such as addiction, Down's syndrome, and epilepsy, which have strong circadian components (Loddenkemper et al., 2011; Zarowski et al., 2011; Cho, 2012; Churchill et al., 2012; Lott, 2012; Stores and Stores, 2012; Ramgopal et al., 2013; Parekh et al., 2015; Webb et al., 2015), are characterized by aberrant GIRK channel function (Kobayashi and Ikeda, 2006; Lüscher and Slesinger, 2010; Arora et al., 2011; Kaufmann et al., 2013). Future studies could investigate whether pharmacological regulators of GIRK channels, such as TPQ or ML297 (a GIRK channel agonist; Days et al., 2010; Wydeven et al., 2014), could be used as therapeutic agents in diseases presenting with circadian rhythm disruption. In support of this future research area, one study has shown that ML297 is effective in reducing signs of epilepsy in mice (Kaufmann et al., 2013).

\section{References}

Agez L, Laurent V, Pévet P, Masson-Pévet M, Gauer F (2007) Melatonin affects nuclear orphan receptors mRNA in the rat suprachiasmatic nuclei. Neuroscience 144:522-530. CrossRef Medline

Agez L, Laurent V, Guerrero HY, Pévet P, Masson-Pévet M, Gauer F (2009) Endogenous melatonin provides an effective circadian message to both the suprachiasmatic nuclei and the pars tuberalis of the rat. J Pineal Res 46:95-105. CrossRef Medline

Arora D, Hearing M, Haluk DM, Mirkovic K, Fajardo-Serrano A, Wessendorf MW, Watanabe M, Luján R, Wickman K (2011) Acute cocaine exposure 
weakens $\mathrm{GABA}(\mathrm{B})$ receptor-dependent G-protein-gated inwardly rectifying $\mathrm{K}+$ signaling in dopamine neurons of the ventral tegmental area. J Neurosci 31:12251-12257. CrossRef Medline

Banach M, Gurdziel E, Jędrych M, Borowicz KK (2011) Melatonin in experimental seizures and epilepsy. Pharmacol Rep 63:1-11. Medline

Benloucif S, Dubocovich ML (1996) Melatonin and light induce phase shifts of circadian activity rhythms in the $\mathrm{C} 3 \mathrm{H} / \mathrm{HeN}$ mouse. J Biol Rhythms 11:113-125. CrossRef Medline

Besing RC, Hablitz LM, Paul JR, Johnson RL, Prosser RA, Gamble KL (2012) Neuropeptide Y-induced phase shifts of PER2::LUC rhythms are mediated by long-term suppression of neuronal excitability in a phase-specific manner. Chronobiol Int 29:91-102. CrossRef Medline

Biello SM (2009) Circadian clock resetting in the mouse changes with age. Age (Dordr) 31:293-303. CrossRef Medline

Bonnefont-Rousselot D, Collin F (2010) Melatonin: action as antioxidant and potential applications in human disease and aging. Toxicology 278: 55-67. CrossRef Medline

Borja NL, Daniel KL (2006) Ramelteon for the treatment of insomnia. Clin Ther 28:1540-1555. CrossRef Medline

Campos Costa I, Nogueira Carvalho H, Fernandes L (2013) Aging, circadian rhythms and depressive disorders: a review. Am J Neurodegener Dis 2:228-246. Medline

Challet E (2007) Minireview: entrainment of the suprachiasmatic clockwork in diurnal and nocturnal mammals. Endocrinology 148:5648-5655. CrossRef Medline

Cho CH (2012) Molecular mechanism of circadian rhythmicity of seizures in temporal lobe epilepsy. Front Cell Neurosci 6:55. Medline

Churchill SS, Kieckhefer GM, Landis CA, Ward TM (2012) Sleep measurement and monitoring in children with Down syndrome: a review of the literature, 1960-2010. Sleep Med Rev 16:477-488. CrossRef Medline

Comai S, Gobbi G (2014) Unveiling the role of melatonin MT2 receptors in sleep, anxiety and other neuropsychiatric diseases: a novel target in psychopharmacology. J Psychiatry Neurosci 39:6-21. CrossRef

Coomans CP, Ramkisoensing A, Meijer JH (2014) The suprachiasmatic nuclei as a seasonal clock. Front Neuroendocrinol 37:29-42.

Days E, Kaufmann K, Romaine I, Niswender C, Lewis M, Utley T, Du Y, Sliwoski G, Morrison R, Dawson ES, Engers JL, Denton J, Daniels JS, Sulikowski GA, Lindsley CW, Weaver CD (2010) Discovery and characterization of a selective activator of the G-protein activated inwardrectifying potassium (GIRK) channel. Updated March 14, 2013. In: Probe reports from the NIH molecular libraries program [Internet]. Bethesda: National Center for Biotechnology Information. Available at http://www. ncbi.nlm.nih.gov/books/NBK143539/

Dubocovich ML (2007) Melatonin receptors: role on sleep and circadian rhythm regulation. Sleep Med 8:34-42. Medline

Dubocovich ML, Markowska M (2005) Functional MT1 and MT2 melatonin receptors in mammals. Endocrine 27:101-110. CrossRef

Dubocovich ML, Rivera-Bermudez MA, Gerdin MJ, Masana MI (2003) Molecular pharmacology, regulation and function of mammalian melatonin receptors. Front Biosci 8:d1093-1108. CrossRef Medline

Dubocovich ML, Hudson RL, Sumaya IC, Masana MI, Manna E (2005) Effect of MT1 melatonin receptor deletion on melatonin-mediated phase shift of circadian rhythms in the C57BL/6 mouse. J Pineal Res 39:113-120. CrossRef Medline

Fowler CE, Aryal P, Suen KF, Slesinger PA (2007) Evidence for association of GABA(B) receptors with Kir3 channels and regulators. J Physiol 580: 51-65. CrossRef Medline

Fu LY, Acuna-Goycolea C, van den Pol AN (2004) Neuropeptide Y inhibits hypocretin/orexin neurons by multiple presynaptic and postsynaptic mechanisms: tonic depression of the hypothalamic arousal system. J Neurosci 24:8741-8751. CrossRef Medline

Furuya M, Miyaoka T, Yasuda H, Yamashita S, Tanaka I, Otsuka S, Wake R, Horiguchi J (2012) Marked improvement in delirium with ramelteon: five case reports. Psychogeriatrics 12:259-262. CrossRef Medline

García JJ, López-Pingarrón L, Almeida-Souza P, Tres A, Escudero P, GarcíaGil FA, Tan DX, Reiter RJ, Ramírez JM, Bernal-Pérez M (2014) Protective effects of melatonin in reducing oxidative stress and in preserving the fluidity of biological membranes: a review. J Pineal Res 56:225-237. CrossRef Medline

Hablitz LM, Molzof HE, Paul JR, Johnson RL, Gamble KL (2014) Suprachiasmatic nucleus function and circadian entrainment are modulated by $\mathrm{G}$ protein-coupled inwardly rectifying (GIRK) channels. J Physiol 592: 5079-5092. CrossRef Medline

Hastings MH, Mead SM, Vindlacheruvu RR, Ebling FJ, Maywood ES, Grosse J (1992) Non-photic phase shifting of the circadian activity rhythm of Syrian hamsters: the relative potency of arousal and melatonin. Brain Res 591:20-26. CrossRef

Hatta K, Kishi Y, Wada K, Takeuchi T, Odawara T, Usui C, Nakamura H; DELIRIA-J Group (2014) Preventive effects of ramelteon on delirium: a randomized placebo-controlled trial. JAMA Psychiatry 71:397-403. CrossRef Medline

Huhman KL, Albers HE (1994) Neuropeptide Y microinjected into the suprachiasmatic region phase shifts circadian rhythms in constant darkness. Peptides 15:1475-1478. CrossRef Medline

Hunt AE, Al-Ghoul WM, Gillette MU, Dubocovich ML (2001) Activation of MT(2) melatonin receptors in rat suprachiasmatic nucleus phase advances the circadian clock. Am J Physiol Cell Physiol 280:C110-C118. Medline

Jain S, Besag FM (2013) Does melatonin affect epileptic seizures? Drug Saf 36:207-215. CrossRef Medline

Jiang ZG, Nelson CS, Allen CN (1995) Melatonin activates an outward current and inhibits Ih in rat suprachiasmatic nucleus neurons. Brain Res 687:125-132. CrossRef Medline

Kato K, Hirai K, Nishiyama K, Uchikawa O, Fukatsu K, Ohkawa S, Kawamata Y, Hinuma S, Miyamoto M (2005) Neurochemical properties of ramelteon (TAK-375), a selective MT1/MT2 receptor agonist. Neuropharmacology 48:301-310. CrossRef Medline

Kaufmann K, Romaine I, Days E, Pascual C, Malik A, Yang L, Zou B, Du Y, Sliwoski G, Morrison RD, Denton J, Niswender CM, Daniels JS, Sulikowski GA, Xie XS, Lindsley CW, Weaver CD (2013) ML297 (VU0456810), the first potent and selective activator of the GIRK potassium channel, displays antiepileptic properties in mice. ACS Chem Neurosci 4:1278-1286. CrossRef Medline

Kobayashi T, Ikeda K (2006) G protein-activated inwardly rectifying potassium channels as potential therapeutic targets. Curr Pharm Des 12:45134523. CrossRef Medline

Kuhlman SJ, McMahon DG (2004) Rhythmic regulation of membrane potential and potassium current persists in SCN neurons in the absence of environmental input. Eur J Neurosci 20:1113-1117. CrossRef Medline

Laudon M, Frydman-Marom A (2014) Therapeutic effects of melatonin receptor agonists on sleep and comorbid disorders. Int J Mol Sci 15: 15924-15950. CrossRef Medline

Liu C, Weaver DR, Jin X, Shearman LP, Pieschl RL, Gribkoff VK, Reppert SM (1997) Molecular dissection of two distinct actions of melatonin on the suprachiasmatic circadian clock. Neuron 19:91-102. CrossRef Medline

Loddenkemper T, Vendrame M, Zarowski M, Gregas M, Alexopoulos AV, Wyllie E, Kothare SV (2011) Circadian patterns of pediatric seizures. Neurology 76:145-153. CrossRef Medline

Lott IT (2012) Neurological phenotypes for Down syndrome across the life span. Prog Brain Res 197:101-121. CrossRef Medline

Luchetti F, Canonico B, Betti M, Arcangeletti M, Pilolli F, Piroddi M, Canesi L, Papa S, Galli F (2010) Melatonin signaling and cell protection function. FASEB J 24:3603-3624. CrossRef

Lüscher C, Slesinger PA (2010) Emerging roles for G protein-gated inwardly rectifying potassium (GIRK) channels in health and disease. Nat Rev Neurosci 11:301-315. CrossRef Medline

McArthur AJ, Gillette MU, Prosser RA (1991) Melatonin directly resets the rat suprachiasmatic circadian clock in vitro. Brain Res 565:158-161. CrossRef Medline

McArthur AJ, Hunt AE, Gillette MU (1997) Melatonin action and signal transduction in the rat suprachiasmatic circadian clock: activation of protein kinase $\mathrm{C}$ at dusk and dawn. Endocrinology 138:627-634. Medline

Miyamoto M (2009) Pharmacology of ramelteon, a selective MT1/MT2 receptor agonist: a novel therapeutic drug for sleep disorders. CNS Neurosci Ther 15:32-51. CrossRef Medline

Mundey K, Benloucif S, Harsanyi K, Dubocovich ML, Zee PC (2005) Phasedependent treatment of delayed sleep phase syndrome with melatonin. Sleep 28:1271-1278. Medline

Muraki Y, Yamanaka A, Tsujino N, Kilduff TS, Goto K, Sakurai T (2004) Serotonergic regulation of the orexin/hypocretin neurons through the 5-HT1A. J Neurosci 24:7159-7166. CrossRef Medline

Nelson CS, Marino JL, Allen CN (1996) Melatonin receptors activate het- 
eromeric G-protein coupled Kir3 channels. Neuroreport 7:717-720. CrossRef Medline

Parekh PK, Ozburn AR, McClung CA (2015) Circadian clock genes: Effects on dopamine, reward and addiction. Alcohol 49:341-349. CrossRef

Partch CL, Green CB, Takahashi JS (2014) Molecular architecture of the mammalian circadian clock. Trends Cell Biol 24:90-99. CrossRef Medline

Paulis L, Simko F, Laudon M (2012) Cardiovascular effects of melatonin receptor agonists. Expert Opin Investig Drugs 21:1661-1678. CrossRef Medline

Pittendrigh CS, Daan S (1976) A functional analysis of circadian pacemakers in nocturnal rodents. J Insect Physiol 46:887-896.

Poirel VJ, Boggio V, Dardente H, Pévet P, Masson-Pévet M, Gauer F (2003) Contrary to other non-photic cues, acute melatonin injection does not induce immediate changes of clock gene mRNA expression in the rat suprachiasmatic nuclei. Neuroscience 120:745-755. CrossRef Medline

Prosser RA (1998) Neuropeptide Y blocks serotonergic phase shifts of the suprachiasmatic circadian clock in vitro. Brain Res 808:31-41. CrossRef Medline

Prosser RA (1999) Melatonin inhibits in vitro serotonergic phase shifts of the suprachiasmatic circadian clock. Brain Res 818:408-413. CrossRef Medline

Prosser RA (2003) Serotonin phase-shifts the mouse suprachiasmatic circadian clock in vitro. Brain Res 966:110-115. CrossRef Medline

Racagni G, Riva MA, Popoli M (2007) The interaction between the internal clock and antidepressant efficacy. Int Clin Psychopharmacol 22:S9-S14. Medline

Ramgopal S, Thome-Souza S, Loddenkemper T (2013) Chronopharmacology of anti-convulsive therapy. Curr Neurol Neurosci Rep 13:339. CrossRef Medline

Rawashdeh O, Hudson RL, Stepien I, Dubocovich ML (2011) Circadian periods of sensitivity for ramelteon on the onset of running-wheel activity and the peak of suprachiasmatic nucleus neuronal firing rhythms in $\mathrm{C} 3 \mathrm{H} /$ HeN mice. Chronobiol Int 28:31-38. CrossRef Medline

Rivera-Bermudez MA, Gerdin MJ, Earnest DJ, Dubocovich ML (2003) Regulation of basal rhythmicity in protein kinase $\mathrm{C}$ activity by melatonin in immortalized rat suprachiasmatic nucleus cells. Neurosci Lett 346(1-2):37-40.

Rivera-Bermudez MA, Masana MI, Brown GM, Earnest DJ, Dubocovich ML (2004) Immortalized cells from the rat suprachiasmatic nucleus express functional melatonin receptors. Brain Res 1002(1-2):21-27.

Roenneberg T, Merrow M (2005) Circadian clocks-the fall and rise of physiology. Nat Rev Mol Cell Biol 6:965-971. CrossRef

Ruiz de Elvira MC, Persaud R, Coen CW (1992) Use of running wheels regulates the effects of the ovaries on circadian rhythms. Physiol Behav 52:277-284. CrossRef Medline

Schaap J, Bos NP, de Jeu MT, Geurtsen AM, Meijer JH, Pennartz CM (1999) Neurons of the rat suprachiasmatic nucleus show a circadian rhythm in membrane properties that is lost during prolonged whole-cell recording. Brain Res 815:154-166. CrossRef Medline

Scott FF, Belle MD, Delagrange P, Piggins HD (2010) Electrophysiological effects of melatonin on mouse Per1 and non-Per1 suprachiasmatic nuclei neurones in vitro. J Neuroendocrinol 22:1148-1156. CrossRef Medline
Shimomura K, Lowrey PL, Vitaterna MH, Buhr ED, Kumar V, Hanna P, Omura C, Izumo M, Low SS, Barrett RK, LaRue SI, Green CB, Takahashi JS (2010) Genetic suppression of the circadian Clock mutation by the melatonin biosynthesis pathway. Proc Natl Acad Sci U S A 107:8399_ 8403. CrossRef Medline

Signorini S, Liao YJ, Duncan SA, Jan LY, Stoffel M (1997) Normal cerebellar development but susceptibility to seizures in mice lacking $G$ proteincoupled, inwardly rectifying $\mathrm{K}+$ channel GIRK2. Proc Natl Acad Sci U S A 94:923-927. CrossRef Medline

Siuciak JA, Fang JM, Dubocovich ML (1990) Autoradiographic localization of 2-[125I]iodomelatonin binding sites in the brains of $\mathrm{C} 3 \mathrm{H} / \mathrm{HeN}$ and C57BL/6J strains of mice. Eur J Pharmacol 180:387-390. CrossRef Medline

Srinivasan V, De Berardis D, Shillcutt SD, Brzezinski A (2012) Role of melatonin in mood disorders and the antidepressant effects of agomelatine. Expert Opin Investig Drugs 21:1503-1522. CrossRef Medline

Stores G, Stores R (2012) Sleep disorders and their clinical significance in children with Down syndrome. Dev Med Child Neurol 55:126-130. CrossRef Medline

Turek FW, Penev P, Zhang Y, van Reeth O, Zee P (1995) Effects of age on the circadian system. Neurosci Biobehav Rev 19:53-58. CrossRef Medline

Uberos J, Romero J, Molina-Carballo A, Muñoz-Hoyos A (2010) Melatonin and elimination of kynurenines in children with Down's syndrome. J Pediatr Endocrinol Metab 23:277-282. Medline

van den Pol AN (2012) Neuropeptide transmission in brain circuits. Neuron 76:98-115. CrossRef Medline

van den Top M, Buijs RM, Ruijter JM, Delagrange P, Spanswick D, Hermes ML (2001) Melatonin generates an outward potassium current in rat suprachiasmatic nucleus neurones in vitro independent of their circadian rhythm. Neuroscience 107:99-108. CrossRef Medline

Vyazovskiy VV, Kopp C, Wigger E, Jones ME, Simpson ER, Tobler I (2006) Sleep and rest regulation in young and old oestrogen-deficient female mice. J Neuroendocrinol 18:567-576. CrossRef Medline

Webb IC, Lehman MN, Coolen LM (2015) Diurnal and circadian regulation of reward-related neurophysiology and behavior. Physiol Behav 143: 58-69. CrossRef Medline

Wu YH, Ursinus J, Zhou JN, Scheer FA, Ai-Min B, Jockers R, van Heerikhuize J, Swaab DF (2013) Alterations of melatonin receptors MT1 and MT2 in the hypothalamic suprachiasmatic nucleus during depression. J Affect Disord 148:357-367. CrossRef Medline

Wydeven N, Marron Fernandez de Velasco E, Du Y, Benneyworth MA, Hearing MC, Fischer RA, Thomas MJ, Weaver CD, Wickman K (2014) Mechanisms underlying the activation of G-protein-gated inwardly rectifying K+ (GIRK) channels by the novel anxiolytic drug, ML297. Proc Natl Acad Sci U S A 111:10755-10760. CrossRef Medline

Zarowski M, Loddenkemper T, Vendrame M, Alexopoulos AV, Wyllie E, Kothare SV (2011) Circadian distribution and sleep/wake patterns of generalized seizures in. Epilepsia 52:1076-1083. CrossRef Medline

Zhou XJ, Jiang XH, Yu GD, Yin QZ (2000) Modulation of circadian rhythm of discharges of suprachiasmatic nucleus neurons in rat hypothalamic slices by melatonin. Sheng Li Xue Bao 52:215-219. Medline 